\title{
RECONCILE THE RELIGION AND SCIENCE EDUCATION MANAGEMENT IN ISLAM
}

\author{
Syamsul Kurniawan \\ State Islamic Insitute of Pontianak, Indonesia \\ Email: syamsul_kurniawan@yahoo.com
}

\begin{abstract}
This research is aimed to reconcile science and religion, and to seek its relevance in the management of non-dichotomous Islamic education. In addition, this research departs from the researcher's anxiety in response to the dichotomous thought between religion and science which in turn manifests in the separation of science and religion in the history of Islamic education management. This results in the current Islamic education that suffers a setback in the development of science. Therefore, in the management of Islamic education, reintegration needs to be done without any dichotomy between religion and science.
\end{abstract}

Keywords: Science, Religion, Islamic Education, Non-Dichotomous

\section{A. Introduction}

Muslims are convinced of the veracity of qauliyah ayat (scriptures) and Qauniyah ayat (universe), and also understand that there is no contradiction or dichotomy between religion and science in Islam. Ontologically, Qauliyah ayat and Qauniyah ayat derived from "The One". Therefore, science and scientists in Islam have a high degree and abreast with the degree of the faithful. As guidance Muslims, the Qur'an is indeed to strengthen integrative relationship between religion and science.

But unfortunately in the trajectory of the history of Muslims has occurred dichotomy between religion and science, afterwards 
appeared awareness of the urgency reintegrating both. Until now dichotomy is still an actual discourse. Partially sighted, between religion and science are two different categories, has a different area of study and oriented to different things. While others say the contrary, both religion and science are the two things that are integrative, two activities are the same and both should not be sorted out, because both can complement each other and can be used for the benefit of mankind.

Grouping of disciplines into discipline of religion and real science are not new, because it appeared at the medieval when Islam began to lose ground. Though, the view religion and science dichotomy were actually not found in the beginning of the history of the Muslims or the classical period of Islam. Dichotomous view in the history of Muslims had caused the backwardness of Islamic scientists in both the development of scientific insights and to resolve the various problems with multimensional approach.

Etymologically, the dichotomy means the division of two parts, division of two, forked part (Echols and Shadily, 1992: 180). The dichotomy can also be interpreted as a division in two conflicting groups (Debdikbud, 1989: 205). While according to the terminology, the dichotomy is the separation between religion and science that later evolved into a phenomenon-dichotomous dichotomous, such as clerical and intellectual dichotomy, a dichotomy in the world of Islamic education and even within the Muslim dichotomy itself (split personality). Ali Anwar Yusuf (2006: 49) explains the dichotomy as a mindset which separates between religion and life. Religion is only is deemed as one of the aspects of life that the human need to worship the Almighty. There another aspects of the religious lives can not be played. This gave rise to a partial understanding of the narrow view of Islam and the growing secularization.

In the management of Islamic education is still a lot of trapped dichotomy. This condition causes the orientation limited to the mastery of the science of religion as such. This pretense makes Islamic education isolated with reality. This orientation should be 
updated so that Islamic education is falling further behind. In the management of Islamic education in Indonesia, the dichotomy of science propagates as a form of differentiator between right distinctively religious school under the auspices of the Ministry of Religious Affairs (MORA) and public schools under the Ministry of Education and Culture (Kemendikbud). School distinctively religious is specifically represented by madrassas / boarding, while public schools are public schools (Muliawan, 2005: 1-2).

This is a research library research (library research) and using the historical approach and philosophy. Questions to be answered in this research is how to reconcile science and religion, and how its relevance in development of Islamic education which is non dichotomous. This study departs from unease writer in responding the thought that dikotomistik between religion and science, which further manifests in the separation of science and religion in the history of Islamic educational management. This resulted in Islamic education output are in worse condition that suffered a setback in the development of science. Therefore, efforts need to be done in managing the integration of Islamic education not dikotomi religion with science. The Benefits of this theoretical study is the theoretical guidance in management of non-Islamic education is dichotomous.

\section{B. Romanticism History of Islamic Civilization}

Decades, the issue of religion and science dichotomy Islamic world did not seem to stop. It always faced with the reality of what is called the distinction between religion and science. It is pointed on the distinction of the term "Islamic science" and "non-Islamic", "western science" and "science of the east". It is worse when this dichotomy spread as a form of dichotomy between science and technology. However, the dichotomy between religion and science is in fact not only in the Islamic world, but in almost all religions.

Historically, Ian G. Barbour (2003), a physicist at once theologian map the relationship of science and religion in four typologies namely conflict, independence, dialogue and integration. 
First, conflict. This relationship is characterized by of two views contradiction between religion and science in view of a problem. They both have arguments that are not only different but also contradictory and negate one another. For example the conflict between religion and science that occurred in the Middle Ages, when the church authorities in 1663 sentenced Galileo Galilei for asking theory of Copernicus and rejected Ptolemy's theory that is supported Aristotle's scientific authority and the authority of scripture believed geocentric. At that time, a person could not accept the views of heliocentric and geocentric at the same, or in other words, it has to choose whether to accept religious truth or the truth of science. Implications the religious truth are a denial of the truth of science and the implications of objectivity science truth is the denial of religious truth even labeled as infidels.

Another issue that illustrates the relationship of conflict between religion and science was about Darwin's theory of evolution which appeared in the nineteenth century. Number of scientists and religionists assumed that Darwin's theory of evolution and the truth of scriptures could not meet. Biblical literalists understood that the universe was created by God directly, while evolutionists argued that the universe came naturally through a very long process or evolution. By demonstrating the empirical evidence evolutionists did not attribute to God such a long process but through a natural process. Living creatures according to evolutionists could develop into a wide range through the mechanism of adaptation, survival for living, and natural selection. For Darwin and evolutionists, human beings are not created specifically and then placed on this earth as the opinion of Biblical literalists. In their opinion, human were just an evolutionary process. This view would shift the view of the church of a God who created the living creatures one by one and specially created human beings who had a higher position than other creatures. There temporary religionists claimed that the theory of evolution wascontrary to religious beliefs, whereas the atheist scientists even argued that the scientific evidence on the theory of evolution was not 
in line with the faith. These two groups agreed that a person might not be able to believe in God and the theory of evolution at the same. Be the religion and science in a contradictory position.

The second, Independence. This view puts the religion and science not in a position of conflict. The truth of religion and science are equally legitimate at while in on the scope of each investigation. The religion and science do not need to interfere with each other because of an understanding of reality that is completely separated from each other, so there is no meaning to contrast the two. In this view smelting effort is unsatisfactory effort to avoid conflicts. An example is the view of the independence among conservative Christians who are trying to melt religion and science by saying that the holy book provide scientific information that the most trustworthy of the beginning the universe and life, which may not contain mistakes. They reject Darwin's theory of evolution and establish a new concept of the creation of is called creation science based on a literal interpretation of the Biblical stories. That religion and science have different methods and issues. Science is built on the observation and human reasoning, while theology based on God's revelation. Therefore, according to the supporters of this understanding the religion and science must walk on their own without any interference with each other. Picture that is often used to describe this typology was as well as a game, such as chess and snakes and ladders. Regulation of the chess can not be applied in the game of snakes and ladders, and vice versa. Likewise science and religion, no one can be compared with each other and both can not be placed in a position to compete or conflict.

This view adequately assessed safely because it can avoid conflicts by separating the relationship between both. The tension between Galileo Galilei with the church for supporters of this understanding should not have to happen if religion can get into the privacy of science, as well as science does not impose themselves with rationalism-empiricism in religion. Religion and science have their own language due to undergo a different function in human life. The 
religion deal with objective facts and susceptible to change because of its deductive, while science may change at any time because it is inductive. In the view of the independent, religion and science are two independent domains that can live together all the maintaince "safe distance" from each other. Religion and science are in a position parallel to each other and not intervene with each other.

Third, dialogue that sees religion and science as something that can not be sealed, boxed-boxed, or something quite separately, although we recognize that they are different logically, linguistics, and normative. This view was born in response to the independence. In this view, the independence although it is a fairly safe option, but can be split to make the reality of life. Acceptance of religious truth and knowledge into a dichotomous choice is ambiguous because it can not be able to take them both. As for someone who try to receive both can be seen a split personality. This is because receiving two kinds of truth that opposing. View of independency can help but let everything in a stalemate that can make someone desperate. Dialogical view departs from the assumption that religion has provided a lot of inspiration for the development of science, as well as scientific discoveries also affect the theology. For example, in the West. Although religion and science can be distinguished within certain limits, but it may not really be separated.

View of this dialogue can build mutual relationship. By learning from science, religion can develop a critical awareness and be more open so it was not too over-sensitive to new things. On the contrary, science needs to consider religious attention on the issue of human dignity. In the human world, there is a reality that forms the mental meaning and value. So knowledge is not the only path to truth, and knowledge is not only for knowledge but also for the humanity. Religion can help to understand the limits of the ratio, namely the region of supernatural or supernatural when knowledge is not able to touch it. A relationship of Dialogical try to compare the methods of both fields that can show similarities and differences. Dialogue can 
occur when the religion and science touching the issue in out of its own territory.

Fourth, integration. There are two characteristics of this view, which is the first that integration implies implicit reintegration, namely reunite religion and science after they are separated, and the second namely the integration of unity implies that religion and science is a primordial unity. The meaning of integration contains the meaning of reintegration that popular in the West from the fact of history which shows that separation. The meaning of integration is as unity more developing in the Islamic world because ontologically believe that the truth of religion and science are one. The difference is the scope of the discussion, which study begins from a reading Qur'an, while the other one starts from a reading of nature. The truth of both support each other and it is not contradict each other.

Historical, classical period of Islam noted that the scientists / intellectuals Muslims saw religion and science as a something integrative. This is manifestation of the ideal concept of Islam as a religion that is perfect (Razaq, 1996: 7), with a comprehensive and universal teachings (Muliawan, 2005: 1).

The Islamic world did experience the supremacy of glory, and the grandeur of civilization, about 6-12 century AD, which is characterized by widespread study of science and philosophy. At that time the Islamic civilization was "lighthouse" world in both the eastern parts of the world and the western world. The romance of the history of Islamic civilization never recorded the name of Muslim scientists and fisuf with gold ink, as in the field of jurisprudence: Imam Malik, Imam Shafi'i, Imam Abu Hanifa, Imam Ahmad ibn Hanbal; in philosophy: al-Kindi, al-Farabi, Avicenna, and Abu Yazid; science: Hayyam Ibn al-Khwarizmi, al-Razi, and al-Mas'udi (Nasution, 1975: 13).

In this century, among science, philosophy and religion are integrated as a single totality. At that time, the degree of knowledge and those who seek it as a "viewpoint of religious" is deemed high and precious. Scientists and philosophers of moslems competed at the time 
holding scientific and philosophical exploration with not tendency at the issue of a sich material. They did so because the spirit of religiosity and motivated by a belief that these activities is an integral part of the manifestation application of religion or God's command (Qutb, 1982: 42-43).

The middle of 12th century AD, the glories of the Muslim in the fields of science in the world, began to shift and bit by bit away from the Islamic world and lived the romance of a sich. It began since the disintegration of the Islamic government that resulted in the emergence of political sects which opposed each other politically. Many sectors, politically proclaimed the closing of the doors of ijtihad and led the people on the interpretation of the religion of exclusive and isolated science and philosophy of the religious dimension. In this century, citing Azra (Mulkhan, et al., 1998: 78-83) appeared separation between profane sciences namely sciences that gave birth to mundane science and technology, which in turn confronted with the religious sciences on the the other side. Automatically it affected the stagnation of Islamic science and fragility as well as the paralysis of the people in various aspects of life.

Muslims began to wake up from sleep length is about the 18th century AD (modern period). The collapse of Egypt into the hands of Western nations awoke and opened the eyes of Muslims that the West has emerged a new higher civilization, as well as a major threat to Muslims (al-Faruqi, 1967: 23). By that moment, Muslim intellectuals who took the initiative to learn science and rational Western sekularistik-materialistic and separated from the spirit and values of Islamic morality. Contiguity with the Islamic of Western science that created competition and response that intersected among the Muslim intellectuals. One the other hand they appeared antagonistic attitudecontradictory, even Western science considered as a works of poor and devoid of religious values. On the other hand, the group of Muslim intellectuals which showed an attitude protagonistcompromising, even glued and fell in methodology secular modern 
science, such as, Muhammad Husayn Haykal, Taha Husain, Ali Abdul Raziq, and others (Bakar, 1991: 220).

These conditions sharpen the gap among science and religion as well as strengthen the dichotomy of science (and common religion; classical and modern; ukhrawi and mundane) which in turn propagated the duality of education. On the one hand, there only deepen education of modern science which is far from the values of Islam. On the other hand, there were educational which only deep religious knowledge that inseparable from the development of modern science.

The rapid development of science and technology (science) in the one hand has led the human on the level of material prosperity, but on the other hand, the paradigm of modern science and technology with various approaches has dragged human dimension aridity and spiritual and moral needs. The rapid progress of science and technology at this time can be said to have made technologization life and livelihood. Be the science and technology developed and increasingly separated himself far abandoned the religion and ethics. This phenomenon indicates the existence of a sharp separation among the life of the world to the Hereafter, which begins with education system that is not integrated, but rather dichotomous partial.

On one side, there is the traditional education system specifically studied Islamic sciences in a narrow, limited legal and worship. On the other sides, there is the education system that emphasizes the secular sciences that adopted raw granted from the West (al-Faruqi, 1984: 12). Both systems generate the duality of personality in the body of Islam and mutually contradictory. In order to deal with this, it is necessary the adoption of modern disciplines secular to Islamic insight, then reintegrated science that has been patterned into education dichotomous Islam.

Dichotomy in Islamic education occurred because the denial of scientific validity and status of one over the other. Religious parties assumed that the general science that was learned heresy or illegitimate because it came from the infidels, while the henchmen the 
general science argued theology as a pseudo science, or in other words as a mythology that would not reach the scientific level. This causes the distance between religious knowledge with general science increasingly distant ". Therefore, the integration of both is a solution that can be offered in order to answer the problems of Islamic education this dichotomy. Integration of science clearly opportunities improving the quality of Islamic education in order to constantly evolve with the progress of the human actualize themselves as a' at once Abdun khalifatullah a'fil-Ardh.

\section{The dichotomy of Islamic Education in Indonesia: At the first}

Historically, the historical dichotomy in Indonesia started since the Dutch colonial period through the colonial education. This education is intended for children of the earth's son and handed over to the mission and the Christian missionaries with financial assistance from the Dutch government. Such education at the beginning of the 20th century had spread to several cities, starting at the primary education up to the upper level consisting of teacher education institutions and vocational schools. Nowadays Dutch colonialism forbid to insert religious instruction in schools and secular colonial aimed at spreading Western culture. This is a form of ethical policy called Political Association for the native Dutch. In addition they are also targeted to be educated cultured West as an attempt countered material advantages that they gained by colonizing Indonesia. This was a project Westernization that made the population into groups and later cornered Western worshiper of Islam, caused in the process of learners crammed with science and secular culture without a counterbalance to religious education (Shihab, 1998: 144).

Another impacts, the Indonesian education divided into two: the Dutch schools were secular, which did not know the doctrines that related to religion; and boarding schools that only taught teachings that related to religion. After independence, the dualism inherited from the Dutch colonial government remains rooted in the world of education in Indonesia. 
This is in line with the analysis Ismail Raji al-Faruqi. According to al-Faruqi (1984: 40-51) and M. Shofwan (2004: 11-12), there were at least two main causes of the phenomenon dichotomy of education in the Islamic world, namely: first, imperialism and western colonialism over the Islamic world. As a result of the terrible damage caused by non-Muslims to Muslims (Century 6 and $7 \mathrm{H} /$ Century 12 and $13 \mathrm{AD}$ ), in the form of the invasion of Tartar army of the East and the Crusaders from the West, Muslim leaders lost their heads and did not have confidence in theirself. However, they took the conservative stance and trying to keep their own identity and the most valuable (Islam) to prohibit all innovation and develop fanaticism at the Shari'ah. At that time they declared the closing of the doors of ijtihad. They treated Shari'ah as a perfect work of the ancestors. They said that any deviation from the law was innovation, and every innovation did not favor and damned. As taught at schools, Shari'ah had to become frozen and thus maintain the safety of Islam. Islamic revival, especially the Muslims victory and expansion to Russia, the Balkans, Central Europe, and Southwestern around the 8th century and the 12th in fact also could not negate the conservative measures. This is in line with the argument that Al-Faruqi, people's views on Islam has been blinded by the sight that brought the colonists.

This view continued to develop until a few generations even though colonialist have gone. This situation affected to all aspects of life at the Muslim society. Furthermore, Al-Faruqi stated that the main factor was the spread of this foreign view were education system; education "modern" education and "Islam". Dualism education system symbolized the downfall of the Muslims. In modern times, Western liberated areas conquered Ottoman in Europe. West occupy, colonize, and divided the Islamic world, except Turkey because here the Western powers were repulsed. While in Yemen and Central Arabia, the West did not appeal to be a colony. So the Muslims were suffered an sich malaise caused by the exploitation of the West. As a response to defeats, tragedies and crises caused by the West in the Islamic world in the last two centuries, Muslim leaders in Turkey, Egypt, and 
India tried to westernization of the people in the hope of making it viable political, economic, and military. The colonization of the West on the Muslim world led to Muslims powerless. In such conditions, it was not easy for Muslims to reject the efforts by the West, especially the injection of modern Western culture and civilization. Inevitably, Western science often replaced the religious sciences in the curriculum of Islamic schools. While efforts to integrate the science of religion and general knowledge (the West) are not done at that time, that happened just a dichotomous separation between theology and general science secular.

Second, the separation between though and action among Moeslims. In the early history of Islam, the leader was thinker and the thinker is the leader. Insights dominant Islam at that time, and desired to achieve insight into the history of Islam in determining all behavior. That preoccupation was from all over Islamic community. Every Muslim was consciously trying to find out the reality of the material and the opportunities to reconstitute into the patterns of Islam. At the same time, a faqih (jurist) was priest, mujtahid, Qari, muhaddits, teachers, mutakallimun, political leaders, generals, farmers or entrepreneurs, and professionals. If anyone felt weak, then the people around him will be happy to assist in overcoming the lack of it. Everyone gave everything for the sake of the ideals of Islam. Later, indivisibility between thought and action is broken. When they are separated, each condition deteriorated.

Political leaders and the policy owner had crises without benefit of thought, without consulting to the cleverly-smart, and did not acquire their wisdom. The result was stagnation (stagnation), which making people felt alienated and increasingly astute leaders' isolation. To maintain their position, political leaders made a mistake that more and larger. On the other hand, foreign and thinkers became increasingly distant from active involvement in the affairs of the people, taking the ideal as their reply in condemning political authority. At that moment a stagnation of thought among Muslims seem real, because did not have assimilation various thoughts and acts 
in it. In fact if the challenge was to respond positively and wisely, the Muslim world would be able to assimilate a new science and could give direction. Al-Faruqi revealed that dichotomy is a symbol of the fall of the Muslims, because in fact every aspect had to be able to reveal the relevance of Islam in all three axes of monotheism. The First, the unity of knowledge; The second, unity of life; and the third, the unity of history. The dichotomy of science as the caused of the prolonged decline of the Muslims has been ongoing since the 16th century until the 17th century, known as the century of stagnation of Islamic thought. This dichotomy in the continuation negative impacted on the progress of Islam.

At least there are four problems resulting from dichotomy general sciences and religious sciences, namely as follows: first, the emergence of ambivalence in the Islamic education system; where during this time, such institutions Islamic schools portray himself as an Islamic educational institution with shades tafaqquh fil al din that considers the issue mu'amalah not arable them; meanwhile, the modernization of the education system by entering the general education curriculum into an institution has changed the image of boarding schools as institutions such adin taffaquh fil. As a result, there has been a shift in the meaning that religious subjects only a stamp stamped to achieve the purpose of modern secular education system. The second, the emergence of gaps between Islamic educational systems and the Islamic teachings. Ambivalent education system reflected the dichotomous view that separated the Islamic religious sciences and general sciences. Third, the disintegration of the Islamic education system, where each system (modern / general) West and religion (Islam) remained adamant maintain selfhood or selfishness. The Fourth, the emergence of inferiority manager of Islamic educational institutions. This is caused by Western education is less appreciated values and moral culture.

Furthermore, the International Institute of Islamic Thought Herndon Virginia states that the dichotomy is one of the major crises which impact to several scopes of people's lives, including: political, 
economic context, and the context of culture and religion (al-Faruqi, 1984: 2- 6).

\section{Reconciling Back of Religion and Science in Islamic Education}

Urgency integration of religion and science in the true Islamic education are not only as a response to the backwardness of Muslims in the sciences, but also in response to the latest Muslims against secular Western science. This is justified by Kuntowijoyo (2006: 5859), which had imposed a condition modernization of the separation between science and religion, between independent science and secular sciences. Naturally, according Kuntowijoyo in this period a lot of Muslims who want a new paradigm which is the result of reconciliation between religion and science or between revelation and reason.

The integration of religion and science become urgent because sometimes we feel that full problematic situation in the modern world is caused by human thought itself. Beyond the progress of science and technology at the moment, actually has a potential that can destroy human dignity. Mankind has indeed successfully organizing the economy, organizing political structure, as well as building an advanced civilization for himself, but at the same time, we also see that the human race has become captive from the results of that creation. Since humans enter modern age, since humans are able to develop the potential of rational, they indeed have freed themselves from the shackles of who irrational and mystical thinking shackles natural law thinking who very binding human freedom. But it turns out in this modern world most people can not escape from the shackles of other types, namely the worship of himself (Kuntowijoyo, 2006: 112), or in other terms we call it dehumanization.

With the integration of religion and science, religion is expected to be meaningful, and vice versa for the science in order not to lose the values of divinity, so that both can be a mercy to its adherents, for the human race, or even the whole universe. 
Quoting the opinion Bambang Sugiharto (in Bagir [ed.], 2005: 45-46), some of the benefits that can be learned from the integration that occurred between religion and science: First, critical awareness and realistic attitude shaped by science is very useful for skinning side the side illusion from a religion, not to destroy religion, but to find things that are more essential from religion. In praxis many things in religious life may be illusory, so make the most religions tend to be oversensitive and easily lead to conflicts in the end it undermined the dignity of the religion itself unnoticed. Second, logical ability and prudence to the conclusion who fostered the scientific world allows us to critically assess all forms of new interpretation is now more frenzy and confusing. Third, through its new findings, the science of religion can stimulate response to constantly rethink his beliefs as new and thus avoid the religion itself from the danger of stagnation. Fourth, the findings of science and technology can also provide new opportunities for religious to increasingly realize the ideals of- concretely, especially with regard to common humanity.

Instead, religion has also contributed to the science, namely: first, keeping the science in order to remain human and always be aware of the problems that must be faced concrete. Religion can always be reminded that science is not the only path to truth and the deepest meaning of human life. In the human world there are realities that make up the inner experience of meaning and value, and it is the region that is not a lot of touched by science or science. Second, religion can also remind science to always defend the value of life and humanity even in the progress of science itself. For example, if the sake of the advancement of science and technology have to sacrifice humans, it should be the opposite is true. Third, religion can help deepen knowledge in the area of exploration possibilities supernatural or supernatural. In addition, if the areas are inevitable from a variety of a serious scientific at this time. Fourth, any religion can always keep the mental attitude of humans that are not easily fall into the pragmatic-instrumental mentality, which considers things considered 
valuable in so far as clear benefits and can be manipulated according to the interests.

It was explained that the dichotomy between religion and science that impact the further decline of the Muslim. This motivates Muslim scientists and scholars to discuss back of urgency reintegration. For some scientists and Muslim scholars, Muslims impossible presuppose progress, without religion mutualist position as an integral part from the development of science. In this context, there arose such terms Islamization of science, ilmuisasi Islam, integration of science, integration and interconnection, and others.

Al-Faruqi argues that religion and science can be integrated, and can start to restore science at its center that is monotheism. This meant that there was a correlation or relationship between science and faith.

Furthermore Kuntowijoyo (2006: 57-58) are considering the importance of ilmuisasi Islam. In this context, Kuntowijoyo argues that religion can be integrated with science when scientists and Islamic' scholars immediate formulation of the theory of science based on the Qur'an and make the Qur'an as a paradigm. Efforts are objectified. Islamic religion serves as objective science, so religious teachings are contained in the Quran can be benefit the whole of nature or become rahmatan lil 'Alamin, meaning not only for Muslims but also non-Muslims can get the benefit from the objectification of religion Islam. Kuntowijoyo states that the core from the integration was to unite the efforts not just combine the revelation of God with the findings of the human mind (sciences integralistic), not exclude God (secularism) or otherwise alienating humans (other worldly asceticism).

If you compare the opinion of both religion and science integration model seem to view Ismail Raji al-Faruqi is more real than the models of integration of religion and science discourse Kuntowijoyo only move at the theoretical level a sich. Imam Suprayogo (in Bagir [ed.], 2005: 49-50) argues that religion and science integration model should make the Quran and Sunnah as the 
grand theory of knowledge, making verses qauniyah and qauliyah, both can be used.

It is line with the opinion of Imam Suprayogo above, Azyumardi Azra (in Bagir 2005: 49-50) that classificate three typologies response Muslim scholars related to the relationship between the Islamic religious sciences with general science. First, Restorationists as saying that science is useful and needed is the practice of religion (worship). The scholars who argued like this is Ibrahim Musa from Andalusia. Ibn Taymiyya said that knowledge is the knowledge from the Prophet . Likewise Abu al-A'la al-Mawdudi, a scholar from Pakistan said that the sciences from the West such as geography, physics, chemistry, biology, zoology, geology, and economics was the source of misguidance because without reference to Allah. And the Prophet Muhammad. Secondly, Reconstruction religious interpretations of modern civilization to improve relations with Islam, with the assumption that Islam during the Prophet Muhammad are very revolutionarily, progressive, and rationalists. Sayyid Ahmad Khan said that the word of God Swt.dan scientific truth were equally true. This opinion is in line with the opinion of Jamaluddin al-Afghani who states that Islam has a scientific spirit. Third, in the sense of reconstructing the Reintegration sciences derived from the verses the Quran and verses qauniyah so it can be returned at transcendental unity of all science.

Azra integration is concerned with combining religion and science without having to remove the uniqueness of each of these scientific. It's just that there are a number of criticisms leveled a number of scientists or scholars Muslim in connection with the integration of religion and science, among them came from M. Amin Abdullah.

M. Amin Abdullah (2006: vii-viii) considers that this far the integration of religion and science are still difficulties, which combines Islamic studies and general studies that sometimes not relationship because they both want to beat each other. Therefore, he thinks is needed some efforts to interconnect the Islamic studies and 
general studies that more wise and prudent. It is understandable that the interconnection discourse by M. Amin Abdullah is an attempt to understand the complexity of the phenomena encountered and lived the life of human beings, so that every building of any science, both religious science, social science, humanities, as well as faulty, can not stand alone. M. Amin Abdullah (2006: vii-viii) argues that religion and science are integrated and interconnected then the scientific disciplines need to work together, mutual courtesies scolds, interdependence, mutual correction and interconnectedness.

The integrated approach-interconnectif was discoursed by M. Amin Abdullah is an approach that is not to crush each other and it does not mean a fusion between religion and science. In detail M. Amin Abdullah (2006: 219-223) is classified into three patterns that is, the pattern of parallel, linear patterns and circular patterns. First, the parallel pattern is a pattern that each style common science and religion walk on their own without any relations and contiguity with each other. Second, the linear pattern is a pattern in which one of them would be excellent, so there will be the possibility of bias. Third, the pattern of circular, that each style science can understand the limitations, shortcomings and weaknesses in each of science, and also willing to take advantage of the findings at scientific tradition other and have the ability to correct the deficiencies inherent in own.

It is understood that the concept of integration and interconnect was discoursed M. Amin Abdullah is an attempt to make a connection between science connectivity or the Islamic religion and science. Estuary of the concept integration and interconnection make the scientific undergone a process of objectification where science is perceived by non-Muslims as a natural or naturally, not as a religious practice. Meanwhile, the Muslims, can still think of it as a part of religious practices and consider as acts of worship. This allows the sciences of Islam as a mercy for all people.

A concrete example of this concept is the Islamic banking practices or theories formulated from the revelation of Allah. As we know that, Islam through the Qur'an and Sunnah has been providing 
ethics and proper behavior in the banking care. This is where Islamic religious get objectivity where the religious ethics become useful knowledge for all people, both Muslims and non-Muslims, even for an atheist can utilize. In the future, as described M. Amin Abdullah, the scientific work patterns integralistik with religious morality humanistic base are required to get in on areas wider as psychology, sociology, anthropology, health, technology, economics, politics, international relations, law and justice, and so on.

According to al-Faruqi (1984: 55-96), as a prerequisite to eliminate the duality of the educational system, which in turn also eliminates the duality of life, to seek a solution of the malaise facing humanity, science must be islamisation, while avoiding the pitfalls and shortcomings of traditional methodologies. The Islamisation of science must observe a number of principles which constitute the essence of Islam. To recast disciplines under the framework of Islam means making theories, methods, principles, and goals to be subject for: the unity of God, the unity of the universe, the unity of knowledge and truth, unity of life, and the unity of mankind. Thus, al-Faruqi offers a solution to this problem of the dichotomy of life of Muslims (including the dichotomy of education) is the Islamization of science in education; namely the integration of the two systems of education between classical Islam and modern Western science through filtration. Islamic education system consists of madrasah primary and secondary, also colleges and Jami'ah at the college level must be combined with a secular system of schools and public universities with the process of Islamization of science.

AlFaruqi offers the Islamization of science in Islamic education, which is by melting two educational systems; traditional and modern, becoming sound Islamic education system. This is intended to eliminate the problems of the education system dichotomy that has been happening among the people. The idea of "Islamization of Science" in Islamic education contains a principle; that Western science not to be rejected, it means should be accepted, but must go 
through a filtering process which stamp with Islamic breath so as not to conflict with the message of the Qur'an and Hadith.

Furthermore, Faisal Ismail (2003: 42-45) argues that the current dichotomy of science in Islamic education can be dammed with a few things, as follows: first, Strengthening and empowering spiritual faith education at every level of education to prevent secularization of science and technology and education; second, avoiding the pragmatic view hedonic permissive assume anything be done (permissive, ibahah). This view can make someone loose in religion; Third, using the method and approach in the implementation of religious education; Fourth, avoid sensible education anthropocentric postulates that man is the center of everything; Fifth, avoid understanding scientism (scientism), which postulates that science is a measure of truth; sixth, rejected understand agnosticism in education, "not believe in God, not believe it Also " indifferent attitude which being ignorant of the existence of God; seventh, infuse awareness to keep the view of "science for science" because it is not in line with Islam; eighth, doing pure research (pure-research) that delivers a person for sense that behind every thing which studied and obtained from the results of these studies there is the Essence of the Creator, the Almighty and All-Everything that govern and control nature.

In the project integration of religion and science in Islamic educational institutions to the author, the term "Islamization" (Islamization) is more suitable. This is because the definition of Islamisation in a broad sense suggests to islamic process, the object is a person or of human beings, not a science as well as other objects. In the context of Islamization of science, which should attach himself to the principle of monotheism is a knowledge seeker, not the science itself. Discourse on integration between religion and science actually have already emerged long enough, should not use the word integration explicitly, among modern Muslims the idea of the necessity to reconcile science and religion, or reason with revelation (faith) has long circulated. Quite popular is also among Muslims the 
view that in the heyday of science in Islamic civilization, science and religion have been integrated.

Citing from Abuddin Nata, et al. (2005: 143-145) dichotomy damming efforts of this science can be done with the integration efforts in science of Islamic education that was published in three models Islamization science, that is: a model of purification, modernism and neomodernism.

Development of non-dichotomous Islamic's education, should also pay attention to some of the runway as follows: first, the normative theological foundation. Islamic doctrine teaches its adherents to enter Islam kaffah (complete) (QS. AlBaqarah: 208). Treatise the Prophet Muhammad is also a mercy to the universe (QS. AlAnbiya ': 107). This teaching implies that every Muslim is required to be an actor religious loyal, concerned and committed to maintain and preserve the teachings and values of Islam in all aspects of life, as well as willing and capable dedicated accordance with interests, talents, abilities and areas of expertise in the field respectively in the perspective of Islam and humanity. Muslims who are able to achieve the criteria that marked with the attitude, that is always read and understand the teachings of the Qur'an and Sunnah, Trying to live by positioning itself as a principal teachings of Islam that loyal, thinkers, reasoner and reviewers, have high commitment to teachings of Islam, ready dedicated in upholding the teachings and values rahmatan lilalamin Islamic values. Fourth this attitude is a manifestation of God itba'syari'at, while itba 'sunnatillah manifested role in the form of constantly reading and understanding the phenomena of nature, physical and psychical phenomena, social phenomena historically and others, put yourself as an observer, reviewer or researcher (researching) so that, have ability keen to analyze and criticize, and dynamic in understanding the phenomenon around, build sensibilities intellectual and sensitivity of the information, in terms of itba 'sunnatillah need to adjust with the ability and expertise each other as a form of professionalism. Obviously that is an indicator of the normative theological foundation that demands the development and 
management of Islamic education so that is not just limited to the areas covered by the natural sciences, social sciences and humanities.

The second, the philosophical foundation. When seen from the aspect of philosophical paradigm of Islamic education as an effort to develop a view of life that Islam, which manifested in the attitude and manifested in skills of daily living, the process and product search, discovery science through study, research and experimentation and utilization in life is the realization of the Caliphate and dedication to the mission of God in the world role in order to seek his blessing in the life hereafter. Science in Islamic life, not only believing the truth of sensual sensory, rational human logic and ethics, but also recognize and believe in the transcendental truth or intuitive (Divine / revelation). Therefore, the development of science and technology are not value free, as is the realization of the mission of the Caliphate and devotion to Him. Ontological science seems to be neutral, in the sense that it can not be natural, capitalists and others. When science to explain the nature of existing. But when describing the changes there or what will happen, or explain how to use the laws of nature and directed in a certain direction, then science is not neutral. In this context, there are two options, that is: Divine choice (the truth) or human option (lust). Thus the development of Islamic education is based on the construct of thought (epistemology) that vertical (the teachings and values of the divine) is a source of consultation, the central and stand as a criterion, hudan, and mercy, while the horizontal (opinions, concepts, theories, scientific findings from both Muslim and non-Muslim scholars) are aligned with each other happened ideal for sharing consulted with the teachings and divine values especially dimension of aksiologis. Such a view will have implications on the model curriculum and teaching and learning in Islamic education that is not only focusing on how science and technology and art describe a variety of programming are facing the Muslims in daily life. In addition, it also seeks to critical examination of the theories and concepts of science is deemed to deviate from the view of Islam as 
well as offering alternatif concepts in the perspective of Islam and how Muslims respond to modern science.

The third, The historical foundation. In the scientific movement or scientific ethos in the history of Islam by Harun Nasution, there are three periods, that is: Initial Period, from among scholars in classical times (8-11 century AD), have among other characteristics implement the teachings of the Koran umtuk use sense, studying not only the science of religion, but science is to exist in the country of China (not theology), developing the science of religion with diligence and develop science by studying and master the science and Greek philosophy of their time so that it appears scholars of fiqh, tawheed, arithmetic, medicine and others, rejected the offer sultan to become civil servants, Medieval period. In this period of rational thought, philosophical and scientific stagnated and downs. Golden rays move to Europe via western students who come to study in Andalusia and translate the Islamic books into Latin. Productivity scholars and Muslim in science and philosophy were disappeared, even in economy, agriculture and also industry declined at that time. The standout political field precisely because of the three superpowersthat is the kingdom of the Ottoman, Safavid and Mughal, Modern Period (19th century AD). Europeans unbeaten in classical times it turns reappear in modern times and dominate the Islamic world. Egypt falls into the hands of Napoleon Bonaparte in 1798, the Mughals conquered England in 1857 AD At that moment the awareness that they have suffered a setback, because then comes the scholars and Islamic thought with ideas aimed at furthering the Islamic world. Traces the history of the implications for the education system is built and developed through Islamic education institution which is a combination of systematic and integral between God and itba itba'syari'ah 'sunnatillah in its curriculum structures that are expected to produce scholars who act rationally and professionally, broad-minded, akhlakul karimah, master of science in addition to the general religious knowledge, and independent. 


\section{E. Conclusion}

Dichotomy in Islamic education occurred, because the denial of scientific validity and status of one over another. Four problems resulting dichotomy general sciences and religious sciences, namely: first, the emergence of ambivalence in Islamic education system; during this time, such institutions Islamic schools portray himself as an Islamic educational institution with shades tafaqquh fil al din that considered the issue of mu'amalah was not their arable ; meanwhile, the modernization of the education system by entering the general education curriculum into an institution has changed the image of schools as institutions adin taffaquh fil. As a result, there has been a shift in the meaning that religious subjects only a stamp which stamped to achieve the purpose of modern secular education system. Second, the apperance of the gap were between the education systems of Islam and teachings of Islam. Ambivalent education system reflected the dichotomous view separating the Islamic religious sciences and general sciences. Third, the disintegration of the Islamic education system, where each system (modern / general) West and religion (Islam) remained adamant maintain selfhood or selfishness. Fourth, there inferiority that managed of Islamic educational institutions. This was because Western education was less appreciated values and moral culture.

The dichotomy was between religion and science in Islamic education subsequent impact on Muslims setback. This is then motivated scientists and Islamic scholars to discuss about the importance of integration of religion with science. For some scientists and Muslim scholars, Muslims impossible presupposes progress, without religion mutualist position as an integral part of the development of science. In the context of this integration, emerges terms to support the integration religion and science projects in Islamic education such as the Islamization of science, ilmuisasi Islam, integration science, integration and interconnection, and others. Development of non-dichotomous Islamic educational, should also pay attention to some of the runway as follows: first, the normative 
theological foundation, secondly, the philosophical foundation, and third, the historical foundation. 


\section{References}

Abdullah, M. Amin. (2006). Islamic Studies di Perguruan Tinggi: Pendekatan Integratif-Interkonektif . Yogyakarta: Pustaka Pelajar.

al-Faruqi, Isma'il Raji. (1967). Science and Traditional Values in Islamic Society, dalam Zygon; Journal of Religion and Science, Vol. 2 Nomor 3. . (1984). Islamisasi Ilmu Pengetahuan, terj. A. Mahyudin. Bandung: Pustaka.

Bagir, Zainal Abidin. (2005). Integrasi Ilmu dan Agama: Interpretasi dan Aksi. Bandung: Mizan.

Bakar, Osman. (1991). Tauhid dan Sains. terj. Yuliani Liputo. Bandung: Pustaka Hidayah.

Barbour, Ian G. (2003). When Science Meet Religion: Enemies, Strangers, or Partner?, terj. ER. Muhammad. Jakarta: Mizan.

Departemen Pendidikan dan Kebudayaan, 1989. Kamus Besar Bahasa Indonesia. Jakarta: Balai Pustaka.

Echols, John M dan Hassan Shadily. (1992). Kamus InggrisIndonesia. Jakarta: Gramedia Utama.

Ismail, Faisal. (2003). Masa Depan Pendidikan Islam di Tengah Kompleksitas Tantangan Modernitas. Jakarta: Bakti Aksara Persada.

Jalaludin dan Usman Said. (1999). Filsafat Pendidikan Islam, cet. III. Jakarta: Raja Grafindo Persada.

Kuntowijoyo. (2006). Islam Sebagai Ilmu: Epistemologi, Metodologi dan Etika. Yogyakarta: Tiara Wacana.

Muhaimin. (2006). Nuansa Baru Pendidikan Islam; Mengurai Benang Kusut Dunia Pendidikan. Jakarta: Rajawali Pers.

Muliawan, Jasa Ungguh. (2005). Pendidikan Islam Integratif. Yogyakarta: Pustaka Pelajar.

Mulkhan, Abdul Munir, dkk. (1998). Religius IPTEK. Yogyakarta: Fakultas Tarbiyah IAIN Sunan Kalijaga Yogyakarta.

Muslih. (1991). Pendidikan Islam di Indonesia. Yogyakarta: Tiara Wacana. 
Nasution, Harun. (1975). Pembaharuan dalam Islam. Jakarta: Bulan Bintang.

Nata, Abuddin, dkk. (2005). Integrasi Ilmu Agama dan Umum. Jakarta: Rajawali Press.

Qutb, Muhammad. (1982). Qabasat min al-Rasul. Makkah: Dar alSyarqi.

Rahardjo, Mudjia. (2002). Quo Vadis Pendidikan Islam. Malang: Cendekia Paramulya.

Ramayulis dan Samsul Nizar. (2009). Filsafat Pendidikan Islam. Jakarta: Kalam Mulia.

Razak, Nashruddin. (1996). Dienul Islam. Bandung: Al-Maarif.

Salim, Moh Haitami dan Syamsul Kurniawan. (2012). Filsafat Ilmu. Pontianak: STAIN Pontianak Press.

Shihab, Alwi. (1998). Membendung Arus, Respon Gerakan Muhammadiyah Terhadap Penetrasi Misi Kristen di Indonesia. Bandung: Mizan.

Shofan, M. (2004). Pendidikan Berparadigma Profetik. Yogyakarta: Ircisod-UMG Press.

Yayasan Penerjemah al-Qur'an. (1980). Al-Qur'an dan Terjemahannya. Medinah: Qadim al-Haramain al-Syarifain.

Yusuf, Ali Anwar. (2006). Islam dan Sains Modern. Bandung: Pustaka Setia. 